\title{
Potassium hydroxide pulping of four non-woods
}

\author{
S. Sutradhar ${ }^{1}$, M. Sarkar ${ }^{2}$, J. Nayeem ${ }^{1}$, M. Sarwar Jahan ${ }^{1 *}$ and C. Tian $^{2}$ \\ ${ }^{1}$ Pulp and Paper Research Division, BCSIR Laboratories, Dhaka, Dr. Qudrat-i-Khuda Road, Dhaka 1205, Bangladesh \\ ${ }^{2}$ China National Pulp and Paper Research Institute, Chaoyang District, Beijing, China
}

\begin{abstract}
Four non-woods such as, dhaincha (Sesbania bispinosa), jute stick (Corchorus capsularis), wheat straw (Triticum aestivum) and corn stalks (Zea mays) were cooked by potassium hydroxide $(\mathrm{KOH})$ at the optimum conditions of soda pulping. Dhaincha, wheat straw and corn stalks were delignified to kappa number 19.4, 13.6 and 19, respectively, while jute stick was not delignified sufficiently (kappa number 32.5). All these four raw materials maintained good yield in $\mathrm{KOH}$ process. Dhaincha produced the highest pulp yield (50.5\%) and wheat straw had the lowest pulp yield (44.7). All pulps were bleached by $\mathrm{D}_{0} \mathrm{E}_{\mathrm{p}} \mathrm{D}_{1}$ bleaching sequences in identical bleaching conditions. Final pulp brightness reached to above $80 \%$ ISO except jute stick pulp. Jute stick pulp reached to $74.9 \%$ brightness only after the consumption of $30 \mathrm{~kg} \mathrm{ClO}_{2} /$ ton of pulp. The overall bleaching yields were $92.6 \%, 88.4 \%, 90.1$ and $90.8 \%$ for dhaincha, jute stick, wheat straw and corn stalks pulps, respectively. The ${ }^{o} \mathrm{SR}$ of these four non-wood bleached pulps was above 20 , consequently improved papermaking in the unrefined state. Beating rapidly increased papermaking properties, as for example, the tensile index of dhaincha pulps increased from 49 N.m/g in the unrefined pulp to $90 \mathrm{~N} . \mathrm{m} / \mathrm{g}$ in the beaten $50{ }^{\circ} \mathrm{SR}$. It can be seen that $\mathrm{KOH}$ is a good substitute to soda process for non-wood.
\end{abstract}

Keywords: Non-wood; Potassium hydroxide pulping; Bleaching; Beating; Papermaking properties

\section{Introduction}

World expected GDP growth in 2018 is $3.6 \%$ (OECD 2017), while the growth in Bangladesh is much higher, $7.1 \%$, consequently cellulose, paper and paperboard consumption will increase significantly. Therefore, Bangladesh needs more fibrous raw materials to meet the demand. Lignocellulosic raw materials come from forest. But the forest area in Bangladesh is very limited and population density is extremely high, which facilitates conversion of forest land into agricultural land.

In this context, substantial amounts of agricultural wastes are generated every year that can be an alternative substitute for lignocellulosic raw materials (Jahan et al., 2016). Jahan et al., (2016) also showed that main crop residue generated in Bangladesh is rice straw, which accounts 78.3 million MT, followed by wheat straw ( 2 million MT). Corn stalks produce about 1.5 million MT. Jute is one of the most important natural fibers in Bangladesh. It generates about 3.5 million MT jute stick in the year of 2013 (FAOSTAT 2016). These can be used as alternative lignocellulosic raw materials. To exploit these wastes, our research group has carried out extensive research on pulping of rice straw, wheat straw, jute stick, dhaincha, mulberry plant, mustard stalks, lentil stalks etc. (Jahan et al., 2013, 2013a, 2016a; Matin et al., 2015; Rahman et al., 2014, 2016; Sarker et al., 2017; ).

But there are numerous limitations on utilizing agricultural wastes as pulping raw materials. i) Collection of agricultural wastes is difficult as these grow scattered areas, ii) these are bulky compared to wood. iii) contain high silica creating problems in recovery plant and paper machine wet end, iv) high content of fines in the raw material hampers machine running, etc. To overcome these limitations, many attempts have been made, such as organic acid pulping (Jahan et al., 2005, 2006; Xu et. al., 2006), potassium hydroxide (KOH) pulping (Huang et al., 2007, 2008; Rodríguez et al., 2008). $\mathrm{KOH}$ pulping is suitable for small scale pulping, the black liquor of which can be used as fertilizer in agriculture (Huang et al., 2007; Jahan et al., 2016a).

Recently our group finds interesting results on potassium hydroxide pulping of kash (Saccharum sponteneum (Jahan et al., 2016a) and rice straw (Jahan et al., 2016b). Kash was easily delignified to kappa number 12.5 with pulp yield of $52.9 \%$ at the conditions of $14 \% \mathrm{KOH}$ expressed as $\mathrm{NaOH}$ for $2 \mathrm{~h}$ at $150^{\circ} \mathrm{C}$. At this condition, pulp yield in soda $(\mathrm{NaOH})$ process was $0.3 \%$ lower with higher kappa number. Potassium based pulping black liquor was also applied in soil amendment and found beneficial on soil properties and the growth of Red amaranthus. Compared to non-amended control soil, black liquor increased Red amaranthus growth by 2.7 times (Jahan et al., 2016a). At the optimum $\mathrm{KOH}$ pulping conditions (alkali charge $12 \%$ as $\mathrm{NaOH}$, cooking temperature $150{ }^{\circ} \mathrm{C}$ for $2 \mathrm{~h}$ and material to liquor ratio, 1:6), rice straw produced pulp yield of $42.4 \%$ with kappa number 
10.3. $\mathrm{KOH}$ pulp bleached to $85 \%$ brightness by $\mathrm{D}_{0} \mathrm{EpD}_{1}$ bleaching sequences with $\mathrm{ClO}_{2}$ consumption of $25 \mathrm{~kg} / \mathrm{ton}$ of pulp (Jahan et al., 2016b). Silica and lignin were separated from the black liquor of $\mathrm{KOH}$ pulping. The amount of recovered silica, lignin and hemicelluloses were 10.4\%, $8.4 \%$ and $13.0 \%$ (Jahan et al. 2016b). The papermaking properties of $\mathrm{KOH}$ pulp from rice straw were slightly better than those of corresponding $\mathrm{NaOH}$ pulp.

Therefore, in this paper, four non-wood such as dhaincha, jute stick, wheat straw and corn stalks pulping was done with $\mathrm{KOH}$. Pulps were bleached by $\mathrm{D}_{0} \mathrm{EpD}_{1}$ bleaching sequences and papermaking properties were evaluated.

\section{Materials and methods}

\section{Raw materials}

Four non-woods : dhaincha, jute stick, wheat straw and corn stalks were collected and cut to $2-3 \mathrm{~cm}$ in length. Thickness of jute stick and dhaincha was $2-3 \mathrm{~mm}$ in size. After determination of the moisture content of air dried raw materials equivalent to 300 gm o.d. (oven dried) was weighed separately in a polyethylene bag for subsequent cooking experiments.

\section{Pulping}

Pulping of dhaincha, jute stick, wheat straw and corn stalks was carried out by $\mathrm{KOH}$ process in an electrically heated 5 lit capacity digester. Active alkali charge was fixed at $16 \%$ as $\mathrm{NaOH}$ on od raw materials. The following parameters were maintained: i) liquor to fiber ratio: $6: 1$ for wheat straw and corn stalk and 5:1 for jute stick and dhaincha, ii) temperature: $150{ }^{\circ} \mathrm{C}$ for wheat straw and corn stalk and $170{ }^{\circ} \mathrm{C}$ for jute stick and dhaincha, iii) Cooking time: $120 \mathrm{~min}$ at maximum temperature. After the desired time of cooking, pulp was filtered and black liquor was collected for subsequent experiment. Pulp was washed with tap water till the removal of all chemicals. The yield of the pulp was determined gravimetrically from the oven-dried weight of raw material. The kappa number of the resulting pulp was determined in accordance with Tappi Test Methods (T 236 om-99).

\section{$D_{0} E p D$, bleaching}

Pulps were bleached by $\mathrm{D}_{0} \mathrm{EpD}_{1}$ bleaching sequences (where $\mathrm{D}$ represents chlorine dioxide and Ep represents peroxide reinforced alkaline extraction). In the first stage $\left(\mathrm{D}_{0}\right)$ of $\mathrm{D}_{0} \mathrm{EpD}$, bleaching sequences $\mathrm{ClO}_{2}$ was $2 \%$. The temperature was $70^{\circ} \mathrm{C}$ in $\mathrm{D}_{0}$ stage for $45 \mathrm{~min}$. Pulp consistency was $10 \%$. The $\mathrm{pH}$ was adjusted to 2.5 by adding dilute $\mathrm{H}_{2} \mathrm{SO}_{4}$. In the alkaline extraction stage, pulp was extracted with $2 \% \mathrm{NaOH}$ and $0.5 \% \mathrm{H}_{2} \mathrm{O}_{2}$ (on od pulp) for $120 \mathrm{~min}$ at $70^{\circ} \mathrm{C}$. Pulp consistency was $10 \%$. The end $\mathrm{pH}$ in the $\mathrm{D}_{1}$ stage was adjusted to 4 on adding dilute $\mathrm{NaOH}$. The $\mathrm{ClO}_{2}$ charge in the $\mathrm{D}_{1}$ was $1 \%$. The brightness was determined in accordance with Tappi Test Methods T525 om 92.

\section{Evaluation of pulps}

The bleached pulps obtained from dhaincha, jute stick, wheat straw, and corn stalks were beaten in a PFI mill in different revolutions and handsheets of about $60 \mathrm{~g} / \mathrm{m}^{2}$ were made in a Rapid Kothen Sheet Making Machine. The papermaking properties determined were according to TAPPI Standard Test Methods. The sheets were tested for tensile (T 494 om-96), burst (T 403 om-97) and tear strength (T 414 om-98) according to TAPPI Standard Test Methods.

\section{Results and discussion}

\section{Raw materials}

As shown in Table I, a-cellulose content in these four raw materials was above $40 \%$, which is acceptable for pulping. The holocelluose content in these raw materials varied from 66 to $77 \%$, which was within the range of wood and important non-woods (Jimmenez et al., 1990). The lowest lignin content was observed in wheat straw and corn stalk that facilitates easier pulping. The ash content was much higher in wheat straw than the other non-woods. The high ash content is disadvantageous in pulping process that creates problems in chemical recovery system.

\section{Pulping}

These raw materials were cooked under identical cooking conditions based on our previous cooking conditions in soda process (Jahan et al., 2004, 2007, 2016b, 2016c). Temperature and material to liquor ratio for dhaincha and jute stick were $170^{\circ} \mathrm{C}$ and 1:5 and for wheat straw and corn stalks were $150^{\circ} \mathrm{C}$ and $1: 6$, respectively. $\mathrm{KOH}$ charge was used as $\mathrm{NaOH}$. As shown in Table II, $\mathrm{KOH}$ cooking resulted in a screened yield and total yield of $48.6 \%$ and $50.5 \%$, respectively for dhaincha. The pulp had a kappa number of 19.4. The pulp yield was much higher and kappa number lower than the previously studied soda-AQ and kraft processes (Jahan et al. 2007). This pulp yield is close to formic acid-peroxyformic acid process (Jahan et al. 2007a). Screened pulp yield and total pulp yield from jute stick were 48.4 and $48.8 \%$, respectively at a kappa number of 32.5. The higher kappa number can be explained by higher lignin content in jute stick (Table I). But the pulp yield and kappa number in $\mathrm{KOH}$ process were higher than the kraft process (Jahan et al., 2016c). This result indicates that jute stick needs more alkali charge in $\mathrm{KOH}$ process. No reject was observed for wheat straw and corn stalks in the employed cooking conditions. Pulp yield in wheat straw was $44.7 \%$ 
Table I. Characteristics of dhaincha, jute stick, wheat straw and corn stalks

\begin{tabular}{ccccc}
\hline Parameter & $\begin{array}{c}\text { Jute stick } \\
\text { (Rahman } \text { et al., 2016) }\end{array}$ & $\begin{array}{c}\text { Dhaincha } \\
\text { (Sarker } \text { et al., 2017) }\end{array}$ & $\begin{array}{c}\text { Wheat straw } \\
\text { (Jahan } \text { et.al., 2016b) }\end{array}$ & $\begin{array}{c}\text { Corn stalks } \\
\text { (Li } \text { et al., 2012) }\end{array}$ \\
\hline Hollo Cellulose, \% & 76.9 & $66-75$ & 65.6 & - \\
Alpha Cellulose, \% & 40.8 & $40-44$ & 40.1 & 39.4 \\
Extractive, \% & 2.2 & $0.4-0.6$ & 0.9 & 2.5 \\
Ash, \% & 0.74 & $1-2$ & 9.7 & 9.9 \\
Klason lignin, \% & 25.3 & $21-23$ & 15.0 & 18.1 \\
Pentosan, \% & 18.1 & $16-19$ & 21.9 & 16.0 \\
\hline
\end{tabular}

Table II. Pulping of four non-woods by KOH process

\begin{tabular}{ccccccc}
\hline Sample & M:L & $\begin{array}{c}\text { Temperature } \\
\left({ }^{\circ} \mathrm{C}\right)\end{array}$ & $\begin{array}{c}\text { Screened yield } \\
(\%)\end{array}$ & $\begin{array}{c}\text { Reject } \\
(\%)\end{array}$ & $\begin{array}{c}\text { Total pulp } \\
\text { yield }(\%)\end{array}$ & Kappa no \\
\hline Dhaincha & $1: 5$ & 170 & 48.6 & 1.93 & 50.5 & 19.4 \\
Jute stick & $1: 5$ & 170 & 48.4 & 0.38 & 48.8 & 32.5 \\
Wheat Straw & $1: 6$ & 150 & 44.7 & 0 & 44.7 & 13.6 \\
Corn Stalk & $1: 6$ & 150 & 45.8 & 0 & 45.8 & 19.0 \\
\hline
\end{tabular}

kappa number 13.6, which were close to the previous results (Jahan et al., 2016a). In that study pulp yield from wheat straw in soda process was $44.0 \%$ at a kappa number 12.0 in the same cooking conditions. Pulp yield in corn stalks was $44.7 \%$ at a kappa number 19.0. Byrd et al. (2006) also showed that screened pulp yield and total pulp yield of corn stalks were $44.5 \%$ and $46.6 \%$ at kappa number 16.5 in soda-AQ process. Sun et al. (2012) also investigated corn stalk pulping by $\mathrm{KOH}$ and $\mathrm{NH}_{4} \mathrm{OH}$. The combined alkaline system effectively removed lignin during pulping. Wheat straw and corn stalks respond better to delignification in $\mathrm{KOH}$ process, resulting lower kappa number and higher pulp yield than other non-woods (Khristova et al., 2002, Hurter and Byrd 2017). Approximately $90 \%$ delignification was achieved at the temperature of $150^{\circ} \mathrm{C}$ for over $30 \mathrm{~min}$. From the pulp yield and kappa number data, it can be inferred that pulp yield from dhaincha in $\mathrm{KOH}$ process is similar or higher than hardwoods in conventional process (Francis et al., 2008).

\section{Bleaching}

All pulps were bleached by $\mathrm{D}_{0} \mathrm{E}_{\mathrm{p}} \mathrm{D}_{1}$ bleaching sequences in identical bleaching conditions. The residual $\mathrm{ClO}_{2}$ data are not shown because of $100 \%$ of the $\mathrm{ClO}_{2}$ consumption in $\mathrm{D}_{0}$ and $\mathrm{D}_{1}$ sequences. As shown in Table III, final pulp brightness reached to above $80 \%$ ISO except jute stick pulp. Jute stick pulp reached to $74.9 \%$ brightness only after the consumption of $30 \mathrm{~kg} \mathrm{ClO}_{2} /$ ton of pulp. This can be explained of higher initial kappa number (Table II). To achieve $80 \%$ brightness, jute stick pulp needs more $\mathrm{ClO}_{2}$ charge. Variation of pulp viscosity among these four different pulps was not prominent. The highest viscosity after Ep stage was 21.3 mPa.s for dhaincha pulp and the lowest viscosity was 18.4 $\mathrm{mPa}$.s for wheat straw pulp. The final pulp viscosity was 17-19, which indicates that the pulp viscosity did not decrease significantly on the applied bleaching conditions. The final kappa number of dhaincha, wheat straw and corn stalks pulp reached to 1.1-1.2, which indicated almost fully bleached pulp. But the same for jute stick pulp was 3.7. Therefore, jute stick was not delignified sufficiently during 
Table III. Bleaching of non-wood KOH pulps

\begin{tabular}{cccccc}
\hline Raw material & Satge & Kappa number & $\begin{array}{c}\text { Viscosity } \\
\text { (mPa.s) }\end{array}$ & $\begin{array}{c}\text { Brightness } \\
(\% \text { ISO) }\end{array}$ & $\begin{array}{c}\text { Yield } \\
(\%)\end{array}$ \\
\hline Dhaincha & $\mathrm{D}_{0}$ & - & - & - & - \\
& $\mathrm{E}_{\mathrm{p}}$ & 4.1 & 21.3 & 61.5 & - \\
& $\mathrm{D}_{1}$ & 1.2 & 19.2 & 81.7 & 92.6 \\
\hline Jute stick & $\mathrm{D}_{0}$ & - & - & - & - \\
& $\mathrm{E}_{\mathrm{p}}$ & 12.3 & 20.6 & 43.2 & - \\
& $\mathrm{D}_{1}$ & 3.7 & 18.7 & 74.9 & 88.4 \\
\hline Wheat straw & $\mathrm{D}_{0}$ & - & - & - & - \\
& $\mathrm{E}_{\mathrm{p}}$ & 3.5 & 18.4 & 60.6 & - \\
& $\mathrm{D}_{1}$ & 1.1 & 17.0 & 81.3 & - \\
\hline Corn stalks & $\mathrm{D}_{0}$ & - & - & - & - \\
& $\mathrm{E}_{\mathrm{p}}$ & 3.6 & 21.1 & 58.8 & 90.8 \\
\hline & $\mathrm{D}_{1}$ & 1.1 & 18.8 & 80.9 & - \\
\hline
\end{tabular}

cooking or $\mathrm{D}_{0}$ stage to get fully bleached pulp. The overall bleaching yields were 92.6, 88.4, 90.1 and $90.8 \%$ for dhaincha, jute stick, wheat straw and corn stalks pulps, respectively. Hurter and Byrd (2017) indicated a total bleaching loss of $6-7 \%$ with typical non-wood fiber at kappa number of 15 . The authors further anticipated a bleaching

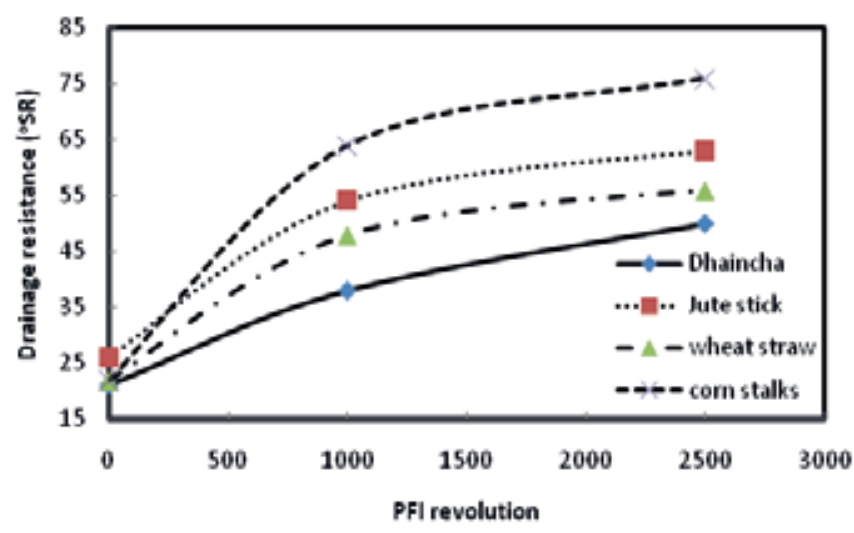

Fig. 1. Increase of drainage resistance of $\mathrm{KOH}$ pulps with PFI revolution

loss of $9-11 \%$ at a kappa number of 20 . Therefore, the bleaching yields are within the expected range.

\section{Papermaking properties}

The refining behaviour of the pulps is shown in Fig. 1 in relation to drainage resistance ( $\left.{ }^{\circ} \mathrm{SR}\right)$ development. The ${ }^{\circ} \mathrm{SR}$ of these four non-wood pulps was above 20, unrefined jute stick pulp had already $26{ }^{\circ} \mathrm{SR}$. With increasing PFI revolution, ${ }^{\circ} \mathrm{SR}$ value of corn stalks and jute stick pulps increased faster compared with dhaincha pulp. At the beating degree of 2500 PFI revolution, ${ }^{\circ} \mathrm{SR}$ value increased from 22 in unrefined state to 76 for corn stalks, while ${ }^{\circ} \mathrm{SR}$ value increased from 21 in unrefined state to 50 for dhaincha pulp. The higher ${ }^{\circ} \mathrm{SR}$ value can be explained by the presence of pith, vessel, and parenchyma in the starting raw materials, which generate fines and increase hydration.

Figs 2-5 show tensile, burst, tear and elongation development in relation to beating degree. Dhaincha and jute stick pulp showed the highest tensile index. The high yield and consequently high-hemicelluloses content in these pulps resulted in good fiber bonding ability and hence high tensile and burst strength. Beating increased the strength properties like tensile and burst strength and elongation. For instance, the tensile index of dhaincha and jute stick pulps increased from $49 \mathrm{~N} . \mathrm{m} / \mathrm{g}$ in the unrefined pulp to $90 \mathrm{~N} . \mathrm{m} / \mathrm{g}$ and 94

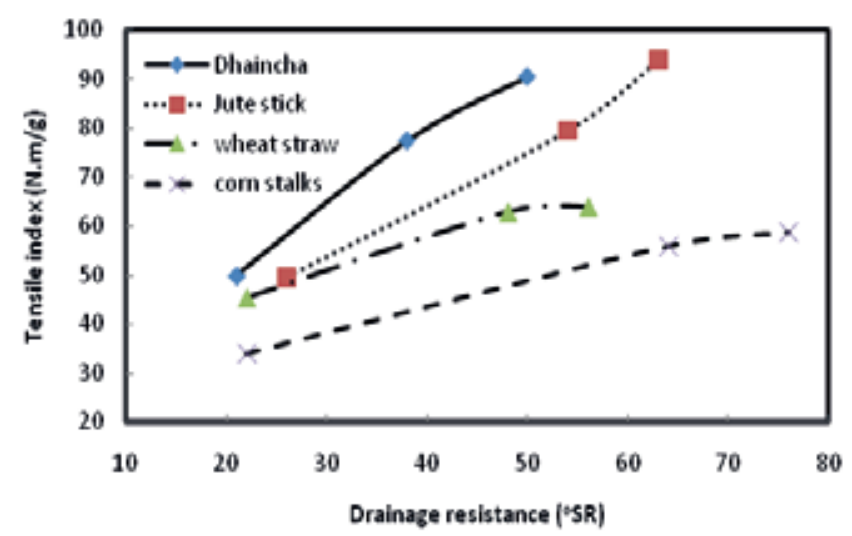

Fig. 2. Tensile index development of $\mathrm{KOH}$ pulps with ${ }^{\circ} \mathrm{SR}$ 


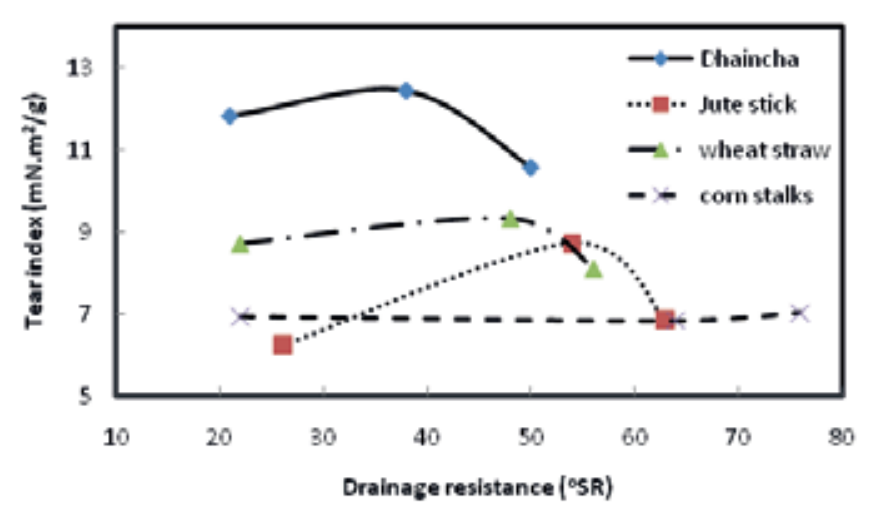

Fig. 3. Tear index development of $\mathrm{KOH}$ pulps with ${ }^{\circ} \mathrm{SR}$

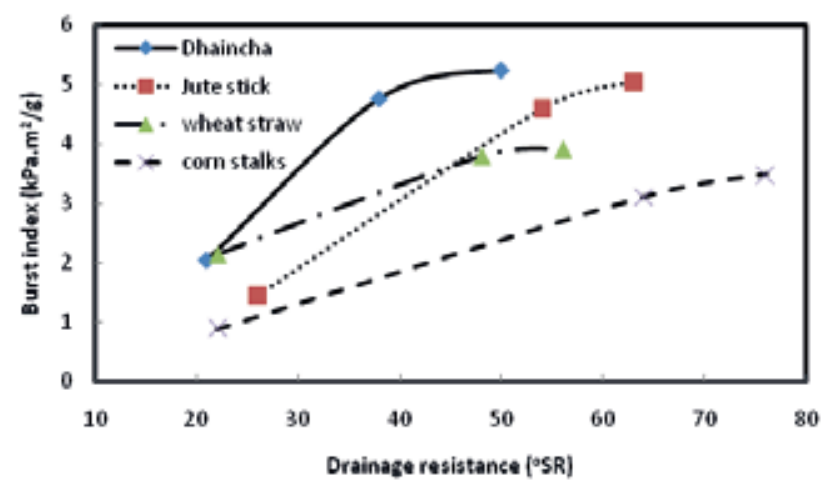

Fig. 4. Burst index development of $\mathrm{KOH}$ pulps with ${ }^{\circ} \mathrm{SR}$

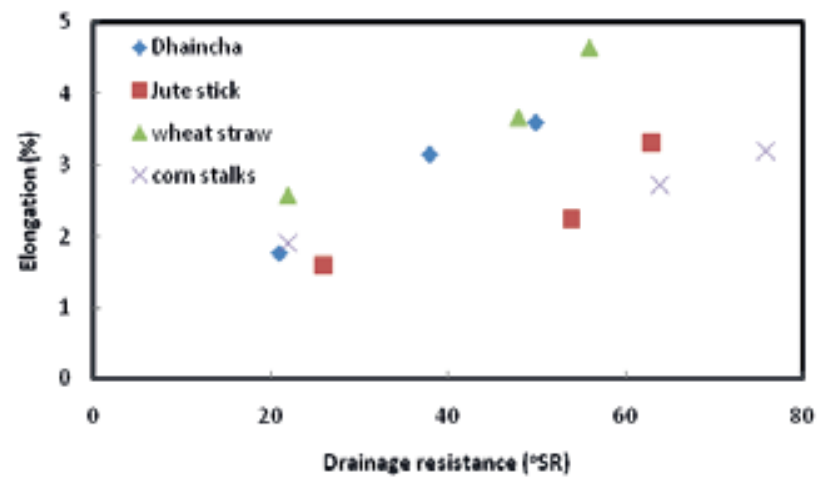

Fig. 5. Elongation development of $\mathrm{KOH}$ pulps with ${ }^{\mathrm{o}} \mathrm{SR}$

$\mathrm{N} . \mathrm{m} / \mathrm{g}$ in the beaten degree 50 and $63^{\circ} \mathrm{SR}$, respectively. Wheat straw and corn stalks pulp also showed good tensile index (58-63 N.m/g). Dhancha pulp showed the highest tear index of $12.4 \mathrm{mN} . \mathrm{m}^{2} / \mathrm{g}$, which was $42.9 \%, 33.3 \%$ and $81.7 \%$ higher than jute stick, wheat straw and corn stalks pulps, respectively. Tear index of corn stalks pulp was independent with beating grade (Fig. 4). Thus, properties of papers obtained from these four non-wood pulps in $\mathrm{KOH}$ process are considerably better than those of other non-wood pulps (Dutt et al., 2008, Enayati et al., 2009). As shown in Fig. 5, elongation of dhaincha and wheat straw pulps showed better results than jute stick and corn stalks pulps.

\section{Conclusion}

Dhaincha, wheat straw and corn stalks was delignified satisfactorily by $\mathrm{KOH}$ in the optimum cooking conditions of soda process on preserving the pulp yield. Dhaincha, wheat straw and corn stalks pulps were bleached to brightness above $80 \%$. The overall bleaching yield of $\mathrm{KOH}$ pulps was 90-93\%. But jute stick was not delignified as desired in applied cooking conditions, consequently showed poor bleachability and lower overall bleaching yield. A good papermaking properties were observed for these four non-wood bleached pulps. The obtained data show that potassium hydroxide $(\mathrm{KOH})$ process could be considered as a promising alternative process for non-wood.

\section{Acknowledgement}

Authors wish to thanks BCSIR for providing necessary fund to carry out this research.

\section{References}

Byrd M, Jameel H, Warby S and Johnson W (2006), Chemical and Pulping Characteristics of Corn Stalk Fractions, 2006 Engineering, Pulping, and Environmental Conference, Atlanta, GA.

Dutt D, Upadhyaya JS, Tyagi CH, Kumar A and Lal M (2008), Studies on Ipomea carnea and Cannabis sativa as an alternative pulp blend for softwood: an optimization of kraft delignification process, Ind. Crop. Prod. 28: 128-136.

Enayati AA, Hamzeh Y, Mirshokraie SA and Molaii M (2009), Papermaking potential of canola stalks, Bioresources 4(1): 245-256.

FAOSTAT (2016) http://faostat3.fao.org/download/F/FO/E

Francis RC, Bolton TS, Abdoulmoumine N, Lavrykova N and Bose SK (2008), Positive and negative aspects of soda/anthraquinone pulping of hardwoods,. Bioresource Technology 99(17): 8453-8457.

Hurter RW and Byrd MV (2017), Pulping and bleaching of Malaysian oil palm empty fruit bunches, Tappi Journal 16(6): 362-371.

Huang GL, Shi JX and Langrish TA (2008), Environmentally friendly bagasse pulping with $\mathrm{NH}_{4} \mathrm{OH}-\mathrm{KOH}-\mathrm{AQ}$, Journal of Cleaner Production 16(12): 1287-1293. 
Huang G, Shi JX and Langrish TA (2007), A new pulping process for wheat straw to reduce problems with the discharge of black liquor, Bioresource technology 98(15): 2829-2835.

Jahan MS, Russel MAN, Shamim SAN, Mostafa AI and Quaiyyum MA (2004), Alkaline pulp of corn stalks, IPPTA J. 16(1): 13-18.

Jahan MS and Mun SP (2005), Effect of tree age on the cellulose structure of Nalita wood (Trema orientalis), Wood Science and Technology 39(5): 367.

Jahan MS, Lee ZZ and Jin Y (2006), Organic acid pulping of rice straw. I: cooking, Turkish journal of agriculture and forestry 30(3): 231-239.

Jahan MS, Chowdhury DAN and Islam MK (2007), Pulping of dhaincha (Sesbania aculeata), Cellulose Chemistry \& Technology 41(7): 413.

Jahan MS, Chowdhury DAN and Islam MK (2007a), Atmospheric formic acid pulping and TCF bleaching of dhaincha (Sesbania aculeata), kash (Saccharum spontaneum) and banana stem (Musa Cavendish), Industrial Crops and Products 26(3): 324-331.

Jahan MS, Rukhsana B, Mojtaba Baktash M, Ahsan L, Fatehi P and Ni Y (2013), Pulping of non-wood and its related biorefinery potential in Bangladesh: A review, Current Organic Chemistry 17(15): 1570-1576.

Jahan MS, Sultana N, Rahman M and Quaiyyum A (2013), An integrated biorefinery initiative in producing dissolving pulp from agricultural wastes, Biomass Conversion and Biorefinery 3(3): 179-185.

Jahan MS, Uddin MN and Akhtaruzzaman AFM (2016), An approach for the use of agricultural by-products through a biorefinery in Bangladesh, The Forestry Chronicle 92(4): 447-452.

Jahan MS, Akter T, Nayeem J, Samaddar PR and Moniruzzaman M (2016a), Potassium hydroxide pulping of Saccharum spontaneum (KASH), J-FOR-Journal of Science \& Technology for Forest Products and Processes 6(1): 46-53.

Jahan MS, Haris F, Rahman MM, Samaddar PR and Sutradhar S (2016b), Potassium hydroxide pulping of rice straw in biorefinery initiatives, Bioresource Technology 219: 445-450.
Jahan MS, Rahman MM, Nayeem J, Islam M and Quaiyyum MA (2016c), Chemical characteristics of ribbon retted jute and its effect on pulping and papermaking properties, Industrial Crops and Products 84: 116-120.

Jimenez L and Lopez F (1990), Characterization of Spanish agricultural residues with a view to obtaining cellulose pulp, TAPPI Journal 73(8): 173-176.

Khristova P, Kordsachia O, Patt R, Khider T and Karrar I (2002), Alkaline pulping with additives of kenaf from Sudan, Industrial Crops and Products 15(3): 229-235.

Li Z, Zhai H, Zhang Y and Yu L (2012), Cell morphology and chemical characteristics of corn stover fractions, Industrial Crops and Products 37(1): 130-136.

Matin M, Rahaman MM, Nayeem J, Sarkar M and Jahan M S (2015), Dissolving pulp from jute stick, Carbohydrate polymers 115: 44-48.

OECD (2017), Real GDP forecast (indicator), doi: 10.1787/1f84150b-en (Accessed on 04 August 2017).

Rahman MM and Jahan MS (2014), Evaluation of mulberry plant as a pulping raw material, Biomass Conversion and Biorefinery 4(1): 53-58.

Rahman MM, Siddiqua S, Akter F, Jahan MS and Quaiyyum MA (2016), Variation of morphological and chemical properties of three varieties of jute stick, Bangladesh Journal of Scientific and Industrial Research 51(4): 307-312.

Rodríguez A, Moral A, Serrano L, Labidi J and Jiménez L (2008), Rice straw pulp obtained by using various methods, Bioresource technology 99(8): 2881-2886.

Sarker M, Sutradhar S, Sarwar AG, Uddin MN, Chanda SC and Jahan MS (2017), Variation of chemical characteristics and pulpability of dhaincha (Sesbania bispinosa) on location, Journal of Bioresources and Bioproducts 2(1): 24-29.

Xu F, Sun JX, Sun R, Fowler P and Baird MS (2006), Comparative study of organosolv lignins from wheat straw, Industrial crops and products 23(2): 180-193. 